\title{
Ruang aktivitas perempuan dalam arsitektur vernakular Gunungsari, Tabanan, Bali
}

\author{
I Wayan Winarta ${ }^{1 *}$ dan I Made Agus Dharmadiatmika²
}

1. Program Studi Magister Arsitektur, Fakultas Teknik, Universitas Udayana, Indonesia 80362

2. Program Studi Arsitektur Pertamanan, Fakultas Pertanian, Universitas Udayana, Indonesia 80225

*E-mail: winartaw@yahoo.com

\begin{abstract}
Space of women activities in vernacular architecture Gunungsari, Tabanan Bali. The space activities of women in the vernacular architecture of Bali has wider position compared with men. Women are given quite a lot of activities space than men, in addition to the ability to give birth and religious activity is high. This underlying pattern in the shape of space on the vernacular architecture of Bali, the Balinese traditional house building pattern that his philosophy is high, where the building is open and it functions more used for women's activities. The process of forming the concept of activity space of the woman, is the answer to the phenomenon of discrimination of women in architecture that is not always true. This research is useful for adding insight deep understanding of vernacular architecture, especially at the Division of spaces according to the person of its activities (gender), a traditional neighborhood development Setup for local residents and businesses for the development of the architectural patterns in rural settlements
\end{abstract}

Keywords: space, the activities of women, vernacular architecture

\section{Pendahuluan}

Dalam konteks perkembangan ilmu pengetahuan, topik arsitektur vernakular dapat dikatakan masih relatif muda. Istilah vernacular sendiri pertama kali diperkenalkan oleh Bernard Rudofsky tahun 1964 melalui pameran yang bertema Architecture without Architects di Museum of Modern Art (MoMA) (Hadinugroho, 2012). Term vernacular ini sendiri berasal dari kata verna (dari bahasa Latin) yang artinya domestic, indigenous, native slave, atau home-born slave, untuk mengklasifikasikan arsitektur lokal (umumnya berupa hunian) yang ditemukannya di berbagai belahan dunia (Rapoport, 2006). Dari sinilah selanjutnya dalam berbagai literatur kontemporer makna yang paling populer bagi arsitektur vernakular adalah arsitektur tanpa arsitek.

Menurut Hadinugroho, (2012) Arsitektur vernakular adalah desain arsitektur yang menyesuaikan iklim lokal, menggunakan teknik dan material lokal, dipengaruhi aspek sosial, budaya, dan ekonomi masyarakat setempat. Faktor iklim lokal (climatic factor) terinspirasi oleh Koenigsberger dalam bukunya yang terbit tahun 1974. Faktor teknik dan material lokal mendapat inspirasi dari Spence dan Cook dalam bukunya (terbit tahun 1983) yang membahas pengaruh material dan teknik lokal pada karya arsitektur vernakular. Pengaruh faktor sosial dan budaya yang membahas secara khusus tentang faktor sosial dan budaya dalam arsitektur vernakular (Rapoport,1969).

Menurut Wardi (2012), Secara ruang spasial rumah tinggal adalah satu kesatuan dari ruang-ruang yang membentuk suatu hirarki. Melalui Hirarki tersebut dapat mencerminkan suatu struktur sosial sistem kekeluargaan penghuni rumah, dalam hal ini adalah keluarga yang terdiri dari ayah, ibu dan anak-anak. Pembentukan hirarki ini dapat dipahami adanya pengorganisasi ruang dalam konteks struktur peran dan kepentingan, yang tidak lain adanya pembagian ruang (space) antara laki-laki dan perempuan. Berkaitan dengan pembagian ruang peran dan kepentingan tersebut, masyarakat dunia modern khususnya kaum feminisme memandang bahwa secara umum budaya hunian tradisional cendrung diskriminatif dalam pembentukkan struktur peran dan kepentingan untuk kaum laki-laki dan kaum perempuan (Ife dan Tesonero, 2008).

Kegiatan berasitektur hunian tradisional umumnya terjadi dominasi, dimulai pada saat perencanaan 
hingga pengambilan keputusan desain ruang hunian adalah kaum laki-laki. Meskipun terdapat konsep kesetimbangan dan pembagian peran yang telah menjadi kesatuan budaya, tetapi kaum perempuan dipandang inferior terhadap kegiatan-kegiatan tersebut. Perempuan diikutsertakan hanya sebatas kendudukannya sebagai "user" yang berperan "pasif". Andaipun pertimbangan-pertimbangan tentang peran kaum perempuan itu ada, hal tidak lain untuk memperkuat dominasi kaum laki-laki terhadap keluarga (Syukrie, 2008).

Menurut Wardi (2012), bahwa peran perempuan dalam berarsitektur hampir tidak tampak. Perempuan terkesan hanya sebagai pengguna karya arsitektur dalam anggota kelompok masyarakat vernakuler (termasuk di Indonesia). Penggunaan karya arsitektur ini untuk menjalankan rutinitas kehidupan sosialnya (anak, remaja, istri dan/atau ibu). Arsitektur sebagai identitas hunian, dimana identitas hunian ini tidak akan terlepas dari peran sosial perempuan. Berbeda hal dengan yang ada di Indonesia, kita justru mengenal adanya istilah-istilah elemen bangunan yang berkaitan dengan perempuan (misalnya: balok induk, ibu tangga) yang menunjukkan perempuan mempunyai peran dalam arsitektur (Soetomo, 2012). Selain itu di Indonesia menyediakan fasilitas dan penataan ruang pada lingkungan hunian untuk memfasilitasi kegiatan dan kepentingan kaum perempuan berdasarkan peranannya dalam keluarga. Melihat peran perempuan yang lebih dominan berada didalam rumah, maka ruang perempuan yang tercipta atas dasar kebutuhan dan kepentingan perempuan itu sendiri. Di sisi lain keberadaaan perempuan sangat diagungkan dalam konsep religi masyarakat tradisional Indonesia.

Selanjutnya perkembangan pola tata ruang tradisional Bali berlaku dari lingkungan terbesar (macro cosmos) sampai ke tingkat ruang terkecil (microcosmos) (Parwata, 1996). Dalam konsep Tri Hita Karana: jiwa, fisik dan tenaga masing-masing disediakan ruangan seperti tempat ibadah keagamaan, tempat aktivitas kehidupan dan tempat-tempat pelayanan umum. Tata nilai ruang didasarkan pada Tri Angga (kepala, badan dan kaki). Parahyangan sebagai tempat ibadah keagamaan, Pawongan sebagai tempat aktivitas kehidupan dan Palemahan sebagai tempat pelayanan umum, masing-masing dinilai sebagai kepala, badan dan kaki. Di lingkungan desa Kahyangan Tiga yakni Pura Desa, Pura Puseh dan Pura Dalem untuk tempat-tempat persembahyangan, desa, pakraman sebagai teritorial desa yaitu tempat pemukiman warga desa, dan kuburan merupakan tempat yang bernilai rendah dari tingkatan tata nilai tradisional, tetapi pada kebanyakan desa di Bali dataran, letak Pura Dalem biasanya berdekatan dengan area kuburan (Siwalatri, 2012).

Gunung Sari adalah salah satu Dusun di Desa Jatiluwih Kecamatan Penebel Kabupaten Tabanan yang memiliki pola Arsitektur Vernakular unik, karena memiliki masa bangunan tradisional Bali yang fungsinya lebih banyak untuk aktivitas perempuan dan memiliki bangunan lumbung padi multi fungsi yang menjadi ciri khas sebagai Desa Agraris dengan budaya pertanian yang tinggi. Dengan pemandangan sawah terasering yang indah dan mempunyai warisan budaya pertanian yang unik, menjadikan kawasan Dusun Gunung Sari banyak dikunjungi oleh wisatawan domistik dan mancanegara apalagi setelah kawasan Jatiluwih ditetapkan sebagai salah satu destinasi Warisan Budaya Dunia oleh UNESCO tahun 2012. Dampak dari penetapan itu adalah pesatnya kunjungan wisatawan, yang pada akhirnya akan berdampak pada beban ekologis kawasan, termasuk pola masa arsitektur Vernakular di kawasan Gunung Sari akibat dari alih fungsi bangunan untuk mengakomodasi pesatnya kunjungan wisatawan, akibat alih fungsi bangunan ini juga berakibat lebih luasnya ruang aktivitas perempuan dalam keluarga di sebuah komunitas keluarga dalam pemanfaatan ruang.

Menurut Wardi (2012) berpendapat bahwa pandangan bahwa selama ini kaum perempuan tidak mempunyai kesempatan untuk berperan karena adanya dominasi dan superioritas dari pihak kaum laki-laki tidak sepenuhnya benar, khususnya untuk ruang perempuan di Indonesia yang mengenal adanya fasilitas dan penataan ruang pada lingkungan hunian untuk memfasilitasi kegiatan kaum perempuan berdasarkan peranannya dalam keluarga. Melihat peran perempuan yang lebih dominan berada didalam rumah, maka ruang perempuan tercipta atas dasar kebutuhan dan kepentingan perempuan itu sendiri. Di sisi lain keberadaaan perempuan sangat diagungkan dalam konsep religi masyarakat tradisional Bali.

Aktivitas ruang perempuan dalam arsitektur vernacular dalam rumah tinggal tradisional Bali di Gunung Sari, juga untuk mengidentifikasi fungsi ruang ruang perempuan tersebut dan mengidentifikasi dan menganalisis faktor-faktor pendorong terjadinya fungsi pada ruang tersebut, pemahaman tentang teori ruang arsitektur, khususnya pada pembagian ruang menurut pelaku-pelaku aktivitasnya (gender) dan masukan bagi para penentu kebijakan penataan pengembangan ruang hunian serta instansi yang terkait dengan penataan ruang permukiman sebagai dasar perencanaan dan penyediaan sarana dan prasarana permukiman 
khususnya permukiman tradisional dan perdesaan.

\section{Metode}

Penelitian dilakukan di Dusun Gunung Sari Desa Jatiluwih Kecamatan Penebel Kabupaten Tabanan. Pendekatan penelitian menggunakan pendekatan deskriptif kualitatif. Data yang dikumpulkan berupa data primer dan data sekunder melalui observasi, pengumpulan literature dan wawancara mendalam terhadap Penglingsir (yang dituakan) dan masyarakat Dusun Gunung Sari. Jumlah responden tidak terbatas dan dapat berkembang sampai dengan data yang diperoleh mangalami titik jenuh.

Pertanyaan wawancara tersusun berdasarkan kebutuhan penelitian. Teknik analisa yang digunakan menggunakan teknik analisa deskriptif dengan mengelompokkan data yang sama kemudian mereduksi data sehingga memeproleh data akhir. Asil analisa kemudian dideskripsikan dan dikaji berdasarkan terori yang ada.

\section{Hasil dan Pembahasan}

Secara umum, hirarkhi dalam pola tata ruang tinggal di Gunung Sari menerapkan konsep Hulu - Teben dengan orientasi sumbu bumi kaja - kelod. Konsep ini tidak hanya diterapkan secara mikro dalam rumah tangga tetapi juga dalam pola desa secara makro. Bangunan - bangunan yang terdapat dalam rumah tinggal tradisional Gunung Sari adalah sebagai berikut :

a. Bangunan Sanggah/Merajan, merupakan banguna tempat suci yang dipergunakan untuk menyelenggarakan kegiatan upacara keagamaan (ritual), uniknya orientasi sanggah di Gunung Sari mengacu kepada jalan sebagai hulu, bukan kaje kangin (Timur-Utara) yang berlaku umum di Bali.

b. Bale Sakenem, merupakan bangunan yang terletak pada daerah kangin, yang dalam keseharian difungsikan sebagai tempat tidur ataupun kegiatan rumah tangga (umumnya bersifat ritual), sedangkan pada saat ada kematian, Bale Sekenem difungsikan sebagai tempat mayat sebelum diberangkatkan ke kuburan. Ciri bangunan ini adalah adanya 6 tiang dengan jarak masing - masing tiang 1-1,5 meter.

c. Bale Saka Roras, merupakan bangunan bertiang 12 yang difungsikan sebagai tempat tidur bagi anggota keluarga yang lebih tua (Orang Tua). Selain itu, bangunan ini difungsikan juga sebagai tempat melakukan kegiatan upacara manusia yandnya bagi keluarga tersebut. Dalam beberapa bangunana Bale Sake Roras yang dilihat dilapangan, dinding bangunan ada dibatasi dengan bambu pada tiap batas pinggir bangunan dan adapula hanya ditembok sebagian yakni pada hulu bangunan.

d. Paon, merupakan bangunan sakenem yang difungsikan sebagai tempat melakukan kegiatan memasak. Disamping fungsi itu tidak jarang di Gunung Sari, Paon juga difungsikan sebagai tempat tidur bagi anggota keluarga, khususnya orang tua disatu komunitas keluarga.

e. Jineng (lumbung), merupakan bangunan yang difungsikan sebagai tempat menyimpan padi. Bangunan ini sudah sangat jarang ditemukan didesa ini.

Bertitik tolak dari hal diatas dasar konsepsi Tri Angga (utama, madya, dan nista) serta berdasarkan hirarkhi ruang dalam tradisional Bali, maka ada 3 tolak ukur yang dipergunakan melihat kecendrungan perkembangan aktivitas ruang perempuan dalam arsitektur vernacular yang ada di Gunung Sari. Gambar 1 berikut adalah kavling masa bangunan yang merupakan satu rangkaian keluarga besar I Nyoman Kanis (50 Tahun) yang terdiri dari 4 (empat) kepala keluarga, ketiga tolak ukur tersebut dapat dilihat sebagai berikut.

a. Pada areal 1, merupakan areal dengan fungsi utama (disakralkan), sehingga apabila terjadi perubahan pada areal ini dinyatakan dengan perubahan besar. Perubahan yang dimaksudkan adalah perubahan akibat dari pergeseran tata letak. Secara fungsi lebih fokus sebagai pusat ritual keluarga besar, dan secara keseharian adalah ruang aktivitas perempuan untuk menghaturkan sesaji setelah memasak makanan, dan upacara dihari-hari tertentu yang dianggap sacral, dengan aturan bagi anggota keluarga yang sedang haid tidak diperkenankan masuk ke area ini, dan digantikan oleh anggota keluarga perempuan yang lain. Aturan umum yang juga berlaku bagi anggota keluarga perempuan adalah bagi yang sedang cuntaka (kondisi dianggap belum suci secara agama hindu) juga tidak diperkenankan masuk pada areal ini.

b. Pada areal 2, merupakan areal dengan fungsi pokok. Perubahan yang terjadi pada areal ini dinyatakan dalam perubahan sedang. Dengan fungsi utama adalah ruang aktivitas utama perempuan pada setiap unit bangunan mulai dari memasak makanan didapur, menyiapkan sarana ritual yang bias dilakukan pada bale dangin. 


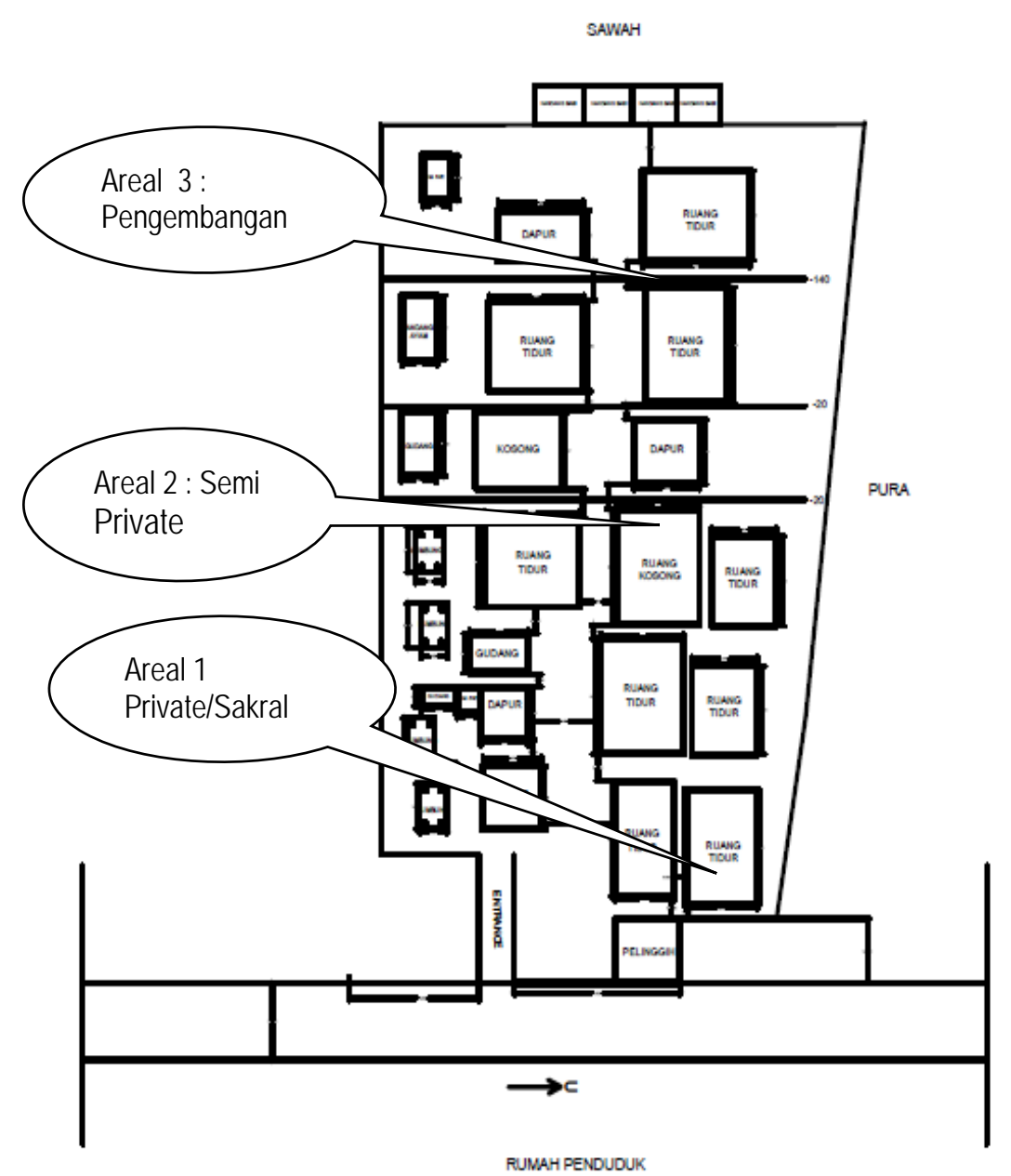

Gambar 1. Pola Masa Bangunan (Hasil Survei, 2016)

pada bangunan jineng, menjemur padi, mengasuh anak, istirahat setelah bekerja dan bersosialisasi dengan anggota keluarga besar. Semua masa bangunan diareal ini dominan digunakan oleh perempuan dalam satu keluarga secara bebas beraktivitas, kecuali pada tempat pelangkiran (ruang suci) tidak diperkenankan menghaturkan sesaji jika dalam kondisi cuntaka (keadaan tidak suci akibat kematian, selama haid).

c. Pada areal 3, merupakan areal dengan fungsi penunjang. Perubahan yang terjadi pada areal ini dinyatakan dalam perubahan kecil. Fungsi utamanya adalah pengembangan masa bangunan jika komunitas keluarga semakin besar dan dibutuhkan masa bangunan baru untuk menampung keluarga yang sudah berkeluarga, bentuk masa bangunan relative sama karena hanya untuk pengembangan, aktivitas perempuan juga sangat dominan di areal ini, kecuali pada saat kondisi yang telah diuraikan diatas.

Dari kajian teori dan kondisi lapangan yang telah diuraikan, maka ruang aktivitas ruang perempuan juga dapat diamati secara lebih detail adalah ruang aktivitas perempuan yang berkaitan dengan aktivitas, ruang, Nama Ruang/Bangunan, peralatan yang menunjukkan keberadaan perempuan), Variabel perubahan fisik ruang perempuan khususnya Br. Gunung Sari, ruang interaksi sosial-budaya, kontruksi bangunan yang mewakili keberadaan perempuan.

Dalam proses pembuatan bangunan, jadi tradisi menjadi referensi yang tetap dalam bangunan vernacular adalah menerapkan kekuatan autoritas tertentu saja. Berbeda dengan ;peranan/rule" dan kadang menerapkan kode tidak tertulis dan bahkan tidak disadari. Tradisi sebagai sebuah referensi pada masa lalu 
oleh karena itu bersifat tidak pasti, dan sebagai sebuah struktur sosial sering dilakukan re-negosiasi pada setiap generasi dan pada setiap komunitas. Menggunakan model linguistik vernakular, tradisi dapat dilihat sebagai bahasa lokal yang mendapatkan penghormatan karena penggunaan yang sering dan lama apalagi yang berkaitan dengan fungsi dan kedudukan perempuan yang sangat dimuliakan. Menurut hasil analisa bahwa ruang aktivitas perempuan yang ada di Desa Jatiluwih khususnya Gunung Sari terbentuk dari beberapa faktor yaitu :

1. Cara pandang masyarakat setempat terhadap semesta (world view), yang membentuk sistem mentalitas masyarakat Gunung Sari dalam kehidupan sehari-hari. Hal yang terpenting dari hasil sistem mentalitas tersebut adalah bagaimana cara pandang masyarakat Gunung Sari terhadap posisi kaum perempuan dalam kehidupannya sehari - hari.

2. Sistem mentalitas tersebut merupakan dasar dalam membentuk sistem budaya, Sosial kemasyarakatan, ekonomi, dan sebagainya.

3. Berdasarkan sistem mentalitas itu pula akan berdampak pada bagaimana masyarakat Gunung Sari dalam membentuk lingkungan fisik mereka sehari-hari.

4. Sistem budaya dan kearifkan local yang telah dimiliki oleh masyarakat Gunung sari dalam bentuk perarem (aturan hukum tradisional) yang dijadikan acuan dan pedoman hidup dalam komunitas masyarakat yang menciptakan keharmonisan hubungan antara manusia dengan manusia, manusia dengan alam serta hubungan manusia dengan Tuhan.

Dari uraian di atas, secara komunitas sosial masyarakat Gunung Sari adalah masyarakat terbuka, dengan pola permukiman yang linear yang mengikuti jalan desa, masa bangunan pada setiap kelompok keluarga terdiri dari 2 sampai dengan 5 kepala keluarga dengan satu pintu masuk dan keluar pada setiap kavling, pada setiap masa bangunan difungsikan sesuai kebutuhan dan fungsi bangunan dalam konsepsi arsitektur tradisional Bali. Setiap masa bangunan baik dalam komunitas keluarga maupun masa bangunan bersama mengikuti aturan dan pola ruang yang sudah ditentukan yaitu mempergunakan konsep Hulu - Teben, dengan jalan sebagai orientasi utama (Gambar 2).

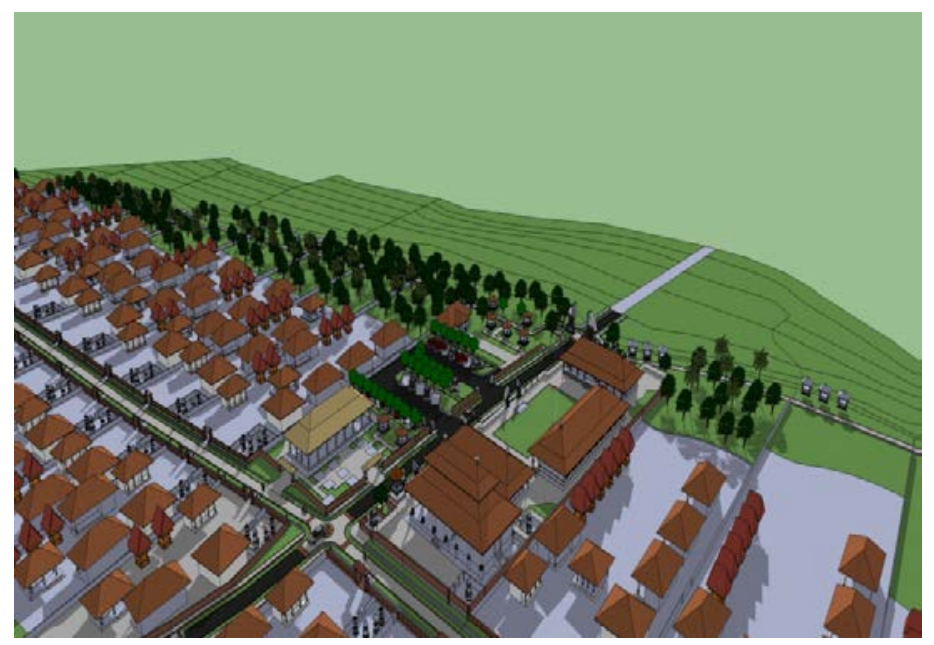

Gambar 2. Pola Masa Bangunan Gunung Sari (Data pribadi, 2012)

Ruang perempuan dalam ruang aktivitas tingkat desa yang diperoleh dari hasil pengamatan, yaitu ketika diadakan upacara adat. ruang yang terbentuk berupa ruang perempuan untuk aktivitas mempersiapkan upacara agama di Pura hal ini tidak boleh tergantikan oleh kaum laki-laki. Ruang tersebut dinamakan bale banjar/wantilan (Gambar 3). Selain itu yang jelas terlihat peran perempuan pada posisi ini dominan, ketika sedang melakukan upacara adat dan Ritual Desa. Perempuan lebih dominan dalam melakukan upacara ini, disebabkan karena perempuan bagi masyarakat Bali sebagai simbol kesejahteraan dan kesuburan dalam kehidupan sehari-hari. Bagi mereka perempuanlah yang pantas untuk persiapan semua sesaji sedangkan laki 
laki hanya menyediakan peralatan dan kebutuhan sesaji.

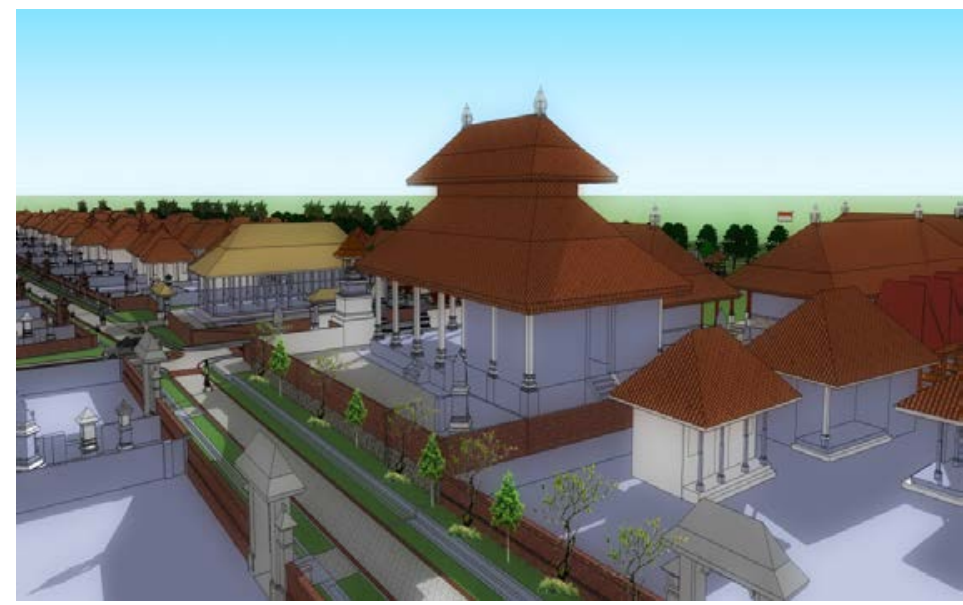

Gambar 3. Wantilan dan Pura Adalah Bagian Ruang Aktivitas Perempuan

Dalam Komunitas Gunung Sari

(Data Pribadi, 2012)

Diluar ruang perempuan untuk aktivitas publik, jenis ruang yang terdapat pada setiap unit keluarga juga menjadi fokus amatan, yaitu beberapa jenis ruang arsitektur vernacular yang berfungsi pokok untuk aktivitas perempuan antara lain : Jineng/Lumbung Padi, sumur bersama, jedhing/Tempat Air, powon/pawon, Sanggah, dan Bale Dangin. Dari hasil analisa aktivitas didapatkan kriteria yang mengisyaratkan sebagai ruang perempuan, karena dari semua aktivitas perempuan berada pada hampir semua masa bangunan yang ada dalam satu pekarangan ini, mulai dari memasak, mengasuh anak, mempersiapkan sesaji, bersosialisasi dengan lingkungan dan dll, Dari hasil wawancara degan Bendesa Adat Desa Jatiluwih di banjar Gunung Sari ada aturan dalam membuat tempat tinggal pawongan, dan ada Pantangan, disekitarnya yaitu : Tidak boleh numbak rurung (Berpapasan dengan gang), dilingkupi oleh pekarangan rumah keluarga, diapit oleh pekarangan keluarga lain (Karang apit), dijatuhi cucuran atap dari rumah orang lain (Karang kelebon amuk) dan berada sebelah jalan umum dan berpapasan (karang negen).

Aturan membangun ini secara turun temurun di ikuti agar tercipta keselarasan hidup, karena rumah menurut kepercayaan mereka memiliki jiwa yang melindungi mereka dalam setiap aktivitas, dan perempuan adalah bagian penting dalam setiap aktivitas kehidupan Gunung Sari, jadi sangat penting bagi komunitas masyarakat Gunung Sari untuk memberikan ruang yang lebih banyak karena aktivitas perempuan Gunung Sari lebih banyak dilakukan di dalam rumah, diluar membantu suami dalam masyarakat agraris. Dalam Tabel 1 berikut dapat diuraikan secara detail fungsi ruang dan aktivitas perempuan di masing-masing bangunan vernacular masyarakat Gunung Sari. 
Tabel 1. Ruang dan Masa Bangunan untuk Aktivitas Perempuan di Banjar Gunung Sari

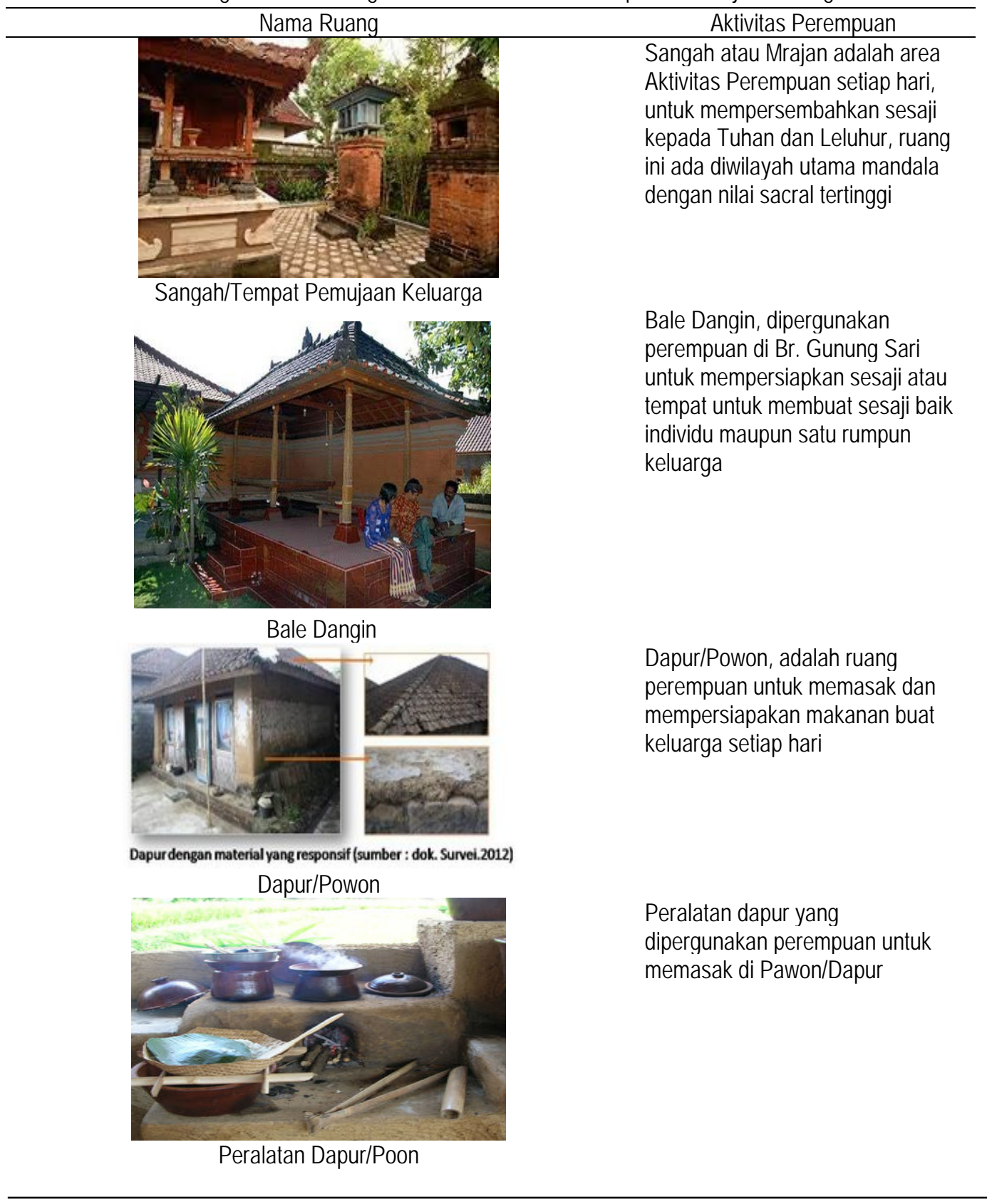



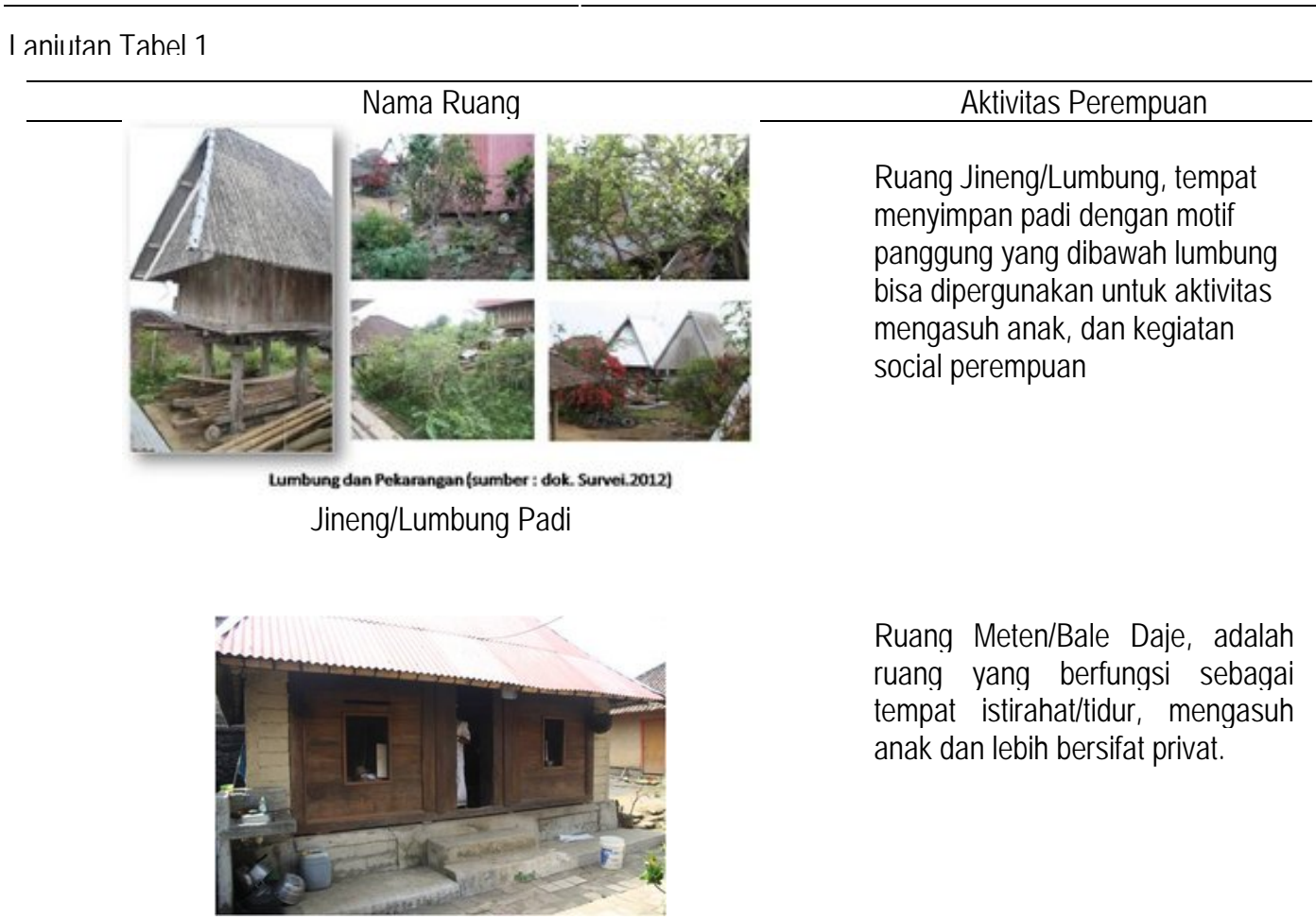

Ruang Meten/Bale Daje, adalah ruang yang berfungsi sebagai tempat istirahat/tidur, mengasuh anak dan lebih bersifat privat.

Bale Meten/Bale Daje

Sumber: Hasil Analisa Pribadi 2016

\section{Simpulan}

Dari hasil uraian dan pengamatan lapangan dapat disimpulkan bahwa ruang aktivitas perempuan didapatkan kriteria yang mengisyaratkan ruang aktivitas perempuan yang berada di area pengamatan khususnya di Br. Gunung Sari yaitu ruang komunitas banjar adat (publik), ruang aktivitas perempuan dalam masa bangunan kumpulan keluarga yang ada di halaman unit hunian dan unit ruang dalam hunian, yaitu berdasarkan dengan kretiria sebagai berikut : aktivitas, peralatan/perlengkapan yang digunakan oleh kaum perempuan ketika beraktivitas sehari-hari, tingkat keprivasian, tingkat kesakralan, mengikuti ketentuan dan pedoman membangun yang sesuai dengan aturan tradisi adat.

Dari kriteria di atas, maka ruang yang mengidentifikasikan sebagai ruang aktivitas perempuan pada unit komunitas adat yaitu Bale Banjar/Wantilan. Halaman hunian atau komunitas keluarga, yaitu Sanggah, Bale Dangin, Bale Daje/meten, Lumbung, dan Dapur. Dari temuan ruang aktivitas perempuan di Br. Gunung Sari, kaum perempuan memiliki kesempatan yang sangat luas beraktivitas dan memberdayakan dirinya di dalam komunitas banjar adat, maupun dalam komunitas keluarga. Anggapan tentang superioritas laki-laki dalam menentukan pola perancangan rumah tinggal tidak sepenuhnya ditunjukkan dalam pembangunan rumah di Br. Gunung Sari, pembangunan memang dilaksanakan oleh kaum laki-laki, tetapi semua kebutuhan dan aktivitas perempuan lebih banyak diperhatikan dalam pembangunannya.

Secara konseptual hunian tradisional yang dilihatkan pada Br. Gunung Sari lebih mengarah pada sistem perlindungan dan pembagian peran antara peran sosial makro dengan peran sosial mikro penghuninya. Dampak pemahaman ini membuat kaum laki-laki cendrung berada pada urusan-urusan yang berhubungan dengan dunia luar hunian, terutama pertanian, perniagaan dan urusan kelompok sosial. Sedangkan perempuan di Br. Gunung Sari cendrung lebih banyak pada urusan dalam rumah tangga (domestic). Jika perempuan bisa memanfaatkan ruang yang dominan diperuntukan untuk mereka beraktivitas diluar aktivitas rutin, akan bisa memberdayakan secara individu maupun kelompok untuk peningkatan ekonomi keluarga secara bersama maupun individu. 


\section{Daftar Pustaka}

Hadinugroho,L. 2002, Ruang dan Prilaku, Suatu Kajian Arsitektural, USU Digital Library.

Ife, J, dan F, Tesonero. 2008, Community Development: Alternatif Pengembangan Masyarakat di Era Globalisasi, Yogyakarta: Penerbit Pustaka Pelajar.

Parwata, 1996, Kajian Pola Tata Ruang Tradisional Bali, Studi Desa Tulamben, Warmadewa Press, Denpasar. Rapoport, A. 1969, House Form and Culture. Prentice Hall, Englewood Cliffs NJ.

Rapoport, A. 2006. Vernacular Design as a Model System. In Asquith, Lindsay and Marcel Vellinga (eds). Vernacular Architecture in the Twenty-First Century. Theory, Education and Practice. London and New York: Taylor \& Francis.

Siwalatri, A. 2012, Tradisi ber-arsitektur masyarakat Sidatapa, Buleleng Bali, Makalah Seminar IAI dan PMA Univ. Udayana, Bali.

Syukrie, S. 2008, Pemberdayaan Perempuan Dalam Pembangunan Berkelanjutan, Makalah Seminar, Denpasar.

Wardi, S. 2012. Pembentukan Konsep Ruang Perempuan Pada Lingkungan Hunian Tradisional Suku Sasak di Dusun Sade Kecamatan Pujut Kab. Lombok Tengah, LPS di mataram. 